\title{
The Implementation of Discovery Learning Model with Scientific Learning Approach to Improve Students' Critical Thinking in Learning History
}

\author{
Edi Nurcahyo*; Leo Agung S; Djono \\ Faculty of Teacher Training and Education, Sebelas Maret University, Indonesia \\ Email: edi.nurcahyo@yahoo.com
}

http://dx.doi.org/10.18415/ijmmu.v5i3.234

\begin{abstract}
Historical learning has not reached optimal in the learning process. It is caused by the history teachers' learning model has not used the innovative learning models. Furthermore, it supported by the perception of students to the history subject because it does not become final exam (UN) subject so it makes less improvement and builds less critical thinking in students' daily learning. This is due to the lack of awareness of historical events and the availability of history books for students and teachers in the library are still lacking. Discovery learning with scientific approach encourages students to solve problems actively and able to improve students' critical thinking skills with scientific approach so student can build scientific thinking include observing, asking, reasoning, trying, and networking
\end{abstract}

Keywords: Discovery learning; Scientific; Critical thinking

\section{Introduction}

Discuss on the subject of learning is concerning to something never last since humans exist, live and thrive on earth until the end of the time. Learning is a process and activity that always done and experienced by humans since in womb, cradle, and grow from children, adolescent, mature, and until to the grave, as a lifetime learning principal by Suyono and Hariyanto (2011: 1). The human developments are encouraged by the systematical learning process, in which the human developments could start from personal, social, transformative, to the altruistic aspect of the human (Abidin, Joebagio, Sariyatun., 2017).

The history learning has not reached optimal in the learning process. It is caused by the history teachers' learning model has not used the innovative learning models. Furthermore, it supported by the perception of students to the history subject because it does not become final exam (UN) subject so it makes less improvement and builds less critical thinking in students' daily learning. This is due to lack of awareness of historical events. The availability of history books for students and teachers in the library still lack. To overcome the lack of critical thinking in history subject as has described above, in this case, the researcher uses a discovery-learning model with the scientific approach to improving students' critical thinking. 
Muhammad Takdir Ilahi (2012: 30) speaks the advantage of discovery learning is a problemsolving modal. Students already applied the principal and the initial step in problem-solving. With this strategy, they have a chance to more intense in solving the problem, so it can be useful to face life in the future. Discovery learning, which focused on the ability to solving a problem relevant to the present development, is required to think about solutes issue that occurs in the midst of the society. That is why, discovery-learning needs to be actualized in real life, allowing students to respond more complex life issues.

According to Daryanto (2014: 51), the learning process could be matched with the scientific process. With scientific approach or scientifically working process, the scientist put forward the inductive reasoning rather than deductive reasoning. Deductive reasoning notices common phenomenon to draw a specific conclusion. On the other hand, inductive reasoning notices specific phenomenon or situation to draw an entirety conclusion. Indeed, inductive reasoning places specific evidence into a broader idea relation. Scientific methods generally place unique phenomena with the study and detail to formulate a general conclusion.

This research is trying to improve the student`s critical thinking by using discovery learning model with a scientific approach. The authors perceive that this improvement could become a solution for the problem of the lack of awareness in the historical learning process. The author's hypotheses that the discovery learning model with scientific approach could improve the student's historical awareness and critical thinking skill in the historical learning process. Thus, this subject is important to be studied to generate the effective solution in the historical learning process as well as it also contributes to the development of theoretical aspect of learning history.

\section{Literature Review Critical Thinking}

Glaser defines critical thinking as an attitude of deep thinking about the problems and matters within the reach of someone's experience, knowledge about examination methods and logical reasoning, kind of skill to apply those methods. Critical thinking strives for a hard effort to examine every assumption or assumptive knowledge based on its supporting evidence and the subsequent conclusion it caused.

According to Alec Fischer (2018: 13), critical thinking is a skillful activity that can be done well or vice versa, and a good critical thinking will meet various intellectual standards, such as clarity, relevance, adequacy, coherence, etc. Critical thinking clearly requires interpretation and evaluation of observation, communication, and other sources of information. It also requires skills in thinking up assumptions, in asking relevant questions, in drawing its short implications, in thinking and debating issues continuously. Furthermore, critical thinkers believe that there are many good ways to decide what to believe or do by using this type of critical and reflective thinking. Therefore, they tend to use these methods whenever the time is right.

Based on Agung and Wahyuni (2013: 56) opinion, the objective of teaching history in school is to enable the students to acquire historical thinking and historical understanding. Through the teaching of history, students would be able to develop the competence to think chronologically and have knowledge about the past. These skills could be used to understand and explain the process of development and change of society and socio-cultural diversity in order to find and nurture the identity of the nation in the midst of the life in the world community. 


\section{Scientific}

Daryanto (2014: 51) mentioned that learning with the scientific approach is a learning process designed in such a way so that learners can actively construct concepts, laws, or principles through observing stages (to identify or find problems), formulate problems, propose or formulate hypotheses, collecting data with various techniques, analyzing data, drawing conclusions, and communicating concepts, laws or principles found.

Learning with scientific approach has a student-centered characteristic, involving skills of science process in constructing concepts, laws, or principles, involves potential cognitive processes in stimulating intellectual development, particularly in students' high-order thinking skill, and can develop students' character.

The objective of learning with a scientific approach based on the advantage of the approach above, some learning objectives with a scientific approach is to improve intellectual skill, especially students' high-order thinking skill. Students can form a skill to solving problem systematically.

The creation of learning situation where students feel that learning is a necessity. Achieve a good learning result. Habituate students in communicating ideas, especially in writing scientific articles, and develop students' character.

The learning process must be avoided from non-scientific traits or values that include intuition, common sense, prejudice, discovery through trial and error, and reckless critical thinking. The general learning steps in scientific approach as mentioned by Aris Shoimin (2014: 166), including observing, asking, reasoning, trying, forming a network for all subjects.

\section{Discovery Learning}

According to Abdulah Sani (2014: 1), education provides a possibility for students to achieve opportunities, expectations, and knowledge to a better life. The greater opportunities and expectations are depended on the quality of education pursued. Education can have a certain quality if students are active in the learning process and teachers are able directly forming values required by students.

Masarudin Siregar in Muhammad Takdir Ilahi (2012: 30) said that discovery learning is a learning process to explore something new in the teaching and learning activities. The learning process could find something if educators firstly prepare the material will be delivered, and then they can do a process to find out important things related to difficulty in learning.

Bruner mentioned that it would be nice if a school could provide opportunities for students' progress in according to the ability of students in certain subjects. In a learning process, Bruner attaches the importance of each student can actively participate and teacher should well know with the differences of students' ability (Slameto., 2013: 11).

Bruner supports the important theoretical which known as discovery learning, a learning model that emphasizes the importance in helping students to understand the basic disciplinary structures or ideas, the need of student's active participation in the learning process, and a belief that learning actually takes place through personal discovery (Rusmono., 2012: 15).

To develop rational and critical thinking skill, the student's ability can be seen through the way they think something. When they have the ability to think rationally and critically, they are able to actualize the thinking potential to face a problem rationally and critically. Rational and critical thinking is 
the manifest of behavior related to problem-solving. Generally, those who think rationally and critically will use the principles and basics in answering questions, such as how and why.

In term of thinking, students are required to use appropriate cognitive strategy to examine the acuity of ideas and the problem solving to overcome the errors and deficiencies. The critical thinking skill obviously will affect its intelligence to overcome the problem itself, so it will emerge a potential that can be developed through the ability to think, examine, and review the reality of a life filled with challenges of the future.

The advantages of discovery learning are the capital in problem-solving and critical thinking skill. The students can immediately apply the principles and the initial steps in problem-solving. Through this strategy, they have an opportunity to be more intense in solving problems, so it can be useful to face the future life.

Discovery learning which focused on the ability to solve something that relevant to the development of the present situation is required to think about a solute issue that occurs in the midst of society. That is why, discovery-learning needs to be actualized in real life, so students are allowed to respond more complex life issues.

The disadvantage of discovery learning is with regard to time. Teaching and learning activities used discovery learning takes time longer than direct methods. It is because, in order to understand this strategy, it takes long stages and needs the ability to manage time as well as possible.

\section{Methodology \\ Research Design}

This study was done in SMK N 6 Surakarta, which is located in Adisucipto Street Number 38, Surakarta, Central Java, Indonesia. The research was conducted in the second semester of the academic year 2017/2018 at X RPL with 31 students.

\section{Research Procedures}

This study is a kind of classroom action research (CAR) which involving writer as a researcher. This research helped by history teacher and students of SMK N 6 Surakarta.

There are many ways teachers can do to solve learning problems in the classroom, and one of them which seen as the effective ways is with classroom action research (CAR). It because during the implementation of CAR, teachers do not leave the main task in teaching and even with CAR the learning process will be more successful (Sarwiji Suwandi., 2009: 7).

CAR is a process of learning improvement which done by teachers in their own classes towards a better learning achievement to be optimal or increased (Hermawan., 2015: 13). The CAR is how a group of teachers can organize their learning condition; and learn from their own experiences. They can try some improvement ideas in their learning process and see the real impression of the effort (Rochia Wiriaatmadja., 2005: 13).

The advantages of CAR are to improve student's achievement, improve teacher's professionalism, develop curriculum, and improve learning innovation. CAR is able to diagnose the problems that affect learning result (Sigit Mangun Wardoyo., 2013: 4). Classroom Action Research used 
to develop a skill or a new approach to solve a problem with direct action in classroom or working field (Samsu Sumadayo., 2013: 23).

Action research can be used effectively to address the gap of theory and practice, to improve educational practices, to empower teachers, to provide teacher professional growth opportunities, to identify educational problems (Craig A. Mertler., 2014: 36).

The purpose of classroom action research is to improve the quality of teaching and learning practice. Through CAR, teachers can constantly improve classroom-learning practices based on real-life experiences guided by the elaboration of knowledge and the mastery of practical and theoretical learning (Sarwiji Suwandi., 2011: 16).

\section{Research Indicator}

The applied of discovery learning method with the scientific approach to learning history can effectively improve critical thinking skill of X RPL SMK N 6 Surakarta in the second-semester academic year 2017/2018. The results of each cycle have increased both individually and classically. The numbers of student who have a minimum criterion of mastery are expected to complete every individual and classical cycle. There was an increase in student achievement on the history subject with minimum criterion mastery at score 75 with the percentage of learning achievement at least $80 \%$.

\section{Result and Discussion}

The implementation of discovery learning model with scientific approach was done in SMK N 6 Surakarta at X RPL on second-semester academic year 2017/2018 in the history subject on Monday. Each cycle consists of four stages as follows: planning, implementing, observing and reflecting. At the initial stage, the teacher was not used the discovery-learning model with scientific approach yet, and there were some low conditions in historical awareness, critical thinking skill, and students' learning achievement. The teacher has improved the learning process in the cycle I by using discovery-learning with the scientific approach.

Hence, with this improvement, the historical awareness, critical thinking skill and learning achievement of the students had increased. The increase of learning achievement in cycle I, teacher was still trying to improve the achievement by doing the cycle II. In the cycle II, the historical awareness, critical thinking skill and learning achievement of the students have more increased. It was shown by the indicator that depicts more than $80 \%$ students have reached the minimum criterion of mastery at score 75 , and students were more active in observing, asking, trying, answering, and concluded the material discussed in historical learning. The result of cycle II has increased both individually and classically so it does not need to implement the cycle III.

The historical learning, which used a discovery-learning model with a scientific approach, has improved students' critical and scientific thinking skills, particularly to help them find problem-solving. The critical thinking skills of the students will be beneficial in their everyday life and for the life to come. These principles and foundations become one of the learners' references in actualizing their rational and critical thinking skills in their daily life. The ability to think rationally and critically can be a major competency in developing their logical power to understand the idea of a problem. Logic as a logical way of thinking is a skill to find a solution to the problems. These skills are demonstrated by scientists and other professionals whose work depends on thought. 
The finding of this research supported Muhammad Takdir Ilahi`s (2012: 30) argumentation that the advantage of discovery learning is a problem-solving modal. The finding of research proved that the discovery learning model provoked the students to find the solution to the problem in the learning process. As Rusmono (2012: 15) emphasize the important theoretical which known as discovery learning, a learning model that emphasizes the importance in helping students to understand the basic disciplinary structures or ideas, the need of student's active participation in the learning process, and a belief that learning actually takes place through personal discovery (Rusmono., 2012: 15). Meanwhile, in the scientific aspect, the finding of this research is in line with Daryanto`s (2014: 51) argumentation that the scientific learning promotes deductive reasoning.

In the aspect of historical learning, the result of research supported Agung and Wahyuni`s (2013: 56) opinion that the objective of teaching history in school is to enable the students to acquire historical thinking and historical understanding, particularly in the critical thinking skill. In line with Alec Fischer (2018: 13), critical thinking is a skillful activity that can be done well or vice versa, and a good critical thinking will meet various intellectual standards, such as clarity, relevance, adequacy, coherence, etc. As Aris Shoumin statements (2014: 116), the learning process must be avoided from non-scientific traits or values that include intuition, common sense, prejudice, discovery through trial and error, and reckless critical thinking. The general learning steps in scientific approach as mentioned include observing, asking, reasoning, trying, forming a network for all subjects.

\section{Conclusion}

This research proved that the discovery learning model and scientific learning approach could improve the student's critical thinking skills. By class action research method, the authors' interference in the learning process by imparting three cycles with discovery learning and scientific approach. The result of student's critical thinking skill in the cycles showed the improvement of learning achievement in cycle I, teacher was still trying to improve the achievement by doing the cycle II. In the cycle II, the historical awareness, critical thinking skill and learning achievement of the students have more increased. Based on the finding of research, the authors conclude that the discovery learning with scientific approach encourages students to solve problems actively and able to improve students' critical thinking skills with scientific approach so student can build scientific thinking include observing, asking, reasoning, trying, and networking.

\section{References}

Abidin, N. F., \& Joebagio, H. (2017). A Path to Altruistic Leader Based on the Nine Values of Indonesian and India Ramayana. Purushartha: A Journal of Management Ethics and Spirituality, 10(2).

Agung, Leo.\&Wahyuni, Sri. (2013). Perencanaan Pembelajaran Sejarah. Yogyakarta: Ombak.

Daryanto. (2014). Pembelajaran Saintifik untuk Implementasi Kurikulum 2013. Yogyakarta: Gava Media.

Fisher, Alec. (2008). Berpikir Kritis Sebuah Pengantar. Jakarta: Erlangga.

Hermawan. (2015). Penelitian Tindakan Kelas \& Penelitian Tindakan Sekolah (Juknis). Surakarta: UNS Press.

Illahi, M.T. (2012). Pembelajaran Discovery Strategy \& Mental Vocational Skill. Jogjakarta: Diva Press. 
Mertler, C. A. (2014). Penelitian Tindakan Kelas Meningkatkan Sekolah dan Memperdayakan Pendidik. Jakarta: Indeks.

Rusmono. (2012). Strategi Pembelajaran dengan Problem Based Learning itu Perlu untuk Meningkatkan Profesional Guru. Bogor: Ghalia Indonesia.

Sani, R.A. (2014). Pembelajaran Saintifik untuk Implementasi Kurikulum 2013. Jakarta: Bumi Aksara.

Aris. (2014). 68 Model Pembelajaran Inovatif dalam Kurikulum 2013. Yogyakarta: Ar-ruzz Media.

Slameto. (2003). Belajar dan Faktor-Faktor yang Mempengaruhinya. Jakarta: Rineka Cipta.

Sumadayo, Samsu. (2013). Penelitian Tindakan Kelas. Yogyakarta: Graha Ilmu.

Suwandi, Sarwiji. (2009). Penelitian Tindakan Kelas (PTK) \& Penulisan Karya Ilmiah. Surakarta: Panitia Sertifikasi Guru (PSG) Rayon 13 Surakarta.

Suwandi, Sarwiji. (2011). Penelitian Tindakan Kelas (PTK) \& Penulisan Karya Ilmiah. Surakarta: Yuma Pustaka.

Suyono \& Hariyanto. (2011). Belajar dan Pembelajaran. Bandung: PT Remaja Rosdakarya.

Wardoyo, S.M. (2013). Penelitian Tindakan Kelas Teori, Metode, Model \& Evaluasi Pembelajaran. Yogyakarta: Graha Ilmu.

Wiriaatmadja Rochiati. (2005). Metode Penelitian Tindakan Kelas untuk Meningkatkan Kinerja Guru dan Dosen. Bandung: PT Remaja Rosdakarya.

\section{Copyrights}

Copyright for this article is retained by the author(s), with first publication rights granted to the journal.

This is an open-access article distributed under the terms and conditions of the Creative Commons Attribution license (http://creativecommons.org/licenses/by/4.0/). 